следовали A. commutatum «Silver King», A. commutatum и A. коммутатум «Malay Beauty», в котором представлены зоны ингибирования $(18,6 \pm 1,2)$ мм, $(16,1 \pm 0,9)$ мм, $(15,7 \pm 1,1)$ мм и $(13,5 \pm 1,0)$ мм соответственно. В случае положительного контроля 96\% этанол обладает мягким анти - E. coli эффектом, который представлен зонами ингибирования $(9,5 \pm 1,2)$ мм. диаметры зон ингибирования были увеличены на 96\% $(p<0,05)$ для A. commutatum «Silver Queen», на 69\% $(p<0,05)$ для A. commutatum «Silver King», на 65\% $(p<0,05)$ для A. commutatum и на $42 \%$ $(p<0,05)$ для A. commutatum «Malay Beauty».

Таким образом, в результате выполненного исследования было экспериментально подтверждено применение этих растений в традиционной медицине и ветеринарии, как потенциального источника сырья для разработки лекарственных средств в будущем, а также для разработки инновачионных кормов для сельскохозяйственных животных.

Ключевые слова: Aglaonema coтmutatum, антимикробная активность, uтамм Escherichia coli (Migula) Castellani and Chalmers $\left(\right.$ ATCC $\left.^{\circledR} 25922^{\mathrm{TM}}\right)$, дискодиффузионный метод Кирби-Бауэра

DOI 10.32900/2312-8402-2020-123-30-38

УДК 615.012.1: 582.949.2: 581.3

\title{
IN VITRO SCREENING FOR ANTIMICROBIAL POTENTIAL OF ETHANOLIC LEAF EXTRACTS OF SOME BEGONIA SPECIES AGAINST METHICILLIN-RESISTANT STAPHYLOCOCCUS AUREUS (MRSA) STRAIN
}

\author{
Tkachenko H., Doctor of Biological Sciences \\ Kurhaluk N., Doctor of Biological Sciences \\ Institute of Biology and Earth Sciences, Pomeranian University in Słupsk, Poland \\ Buyun L., Doctor of Biological Sciences \\ M. M. Gryshko National Botanic Garden, National Academy of Science of Ukraine \\ Tomin V., Doctor of Physical Sciences \\ Pomeranian University in Słupsk, Poland
}

The antimicrobial activities of ethanolic extracts obtained from the leaves of Begonia solimutata L.B. Sm. \& Wassh., Begonia goegoensis N.E.Br., Begonia foliosa Kunth, Begonia $\times$ erythrophylla Hérincq, Begonia thiemei C.DC., Begonia peltata Otto \& Dietr., Begonia heracleifolia Cham. \& Schltdl., Begonia dregei Otto \& Dietr., and Begonia mexicana G. Karst. ex Fotsch were assessed against methicillin-resistant Staphylococcus aureus (MRSA) strain. The leaves were brought into the laboratory for antimicrobial studies. Freshly crushed leaves were washed, weighed, and homogenized in 96\% ethanol (in proportion 1:19) at room temperature. The extracts were then filtered and investigated for their antimicrobial activity. The testing of the antibacterial activity of the plant extracts was carried out in vitro by the Kirby-Bauer disc diffusion susceptibility test protocol. The most effective plants among species screened against $S$. aureus NCTC 12493 growth were B. peltata, B. thiemei, B. foliosa, Begonia $\times$ erythrophylla, and B. solimutata being highly active with the ethanolic extracts (diameters of inhibition zone ranged from 12.5 to $21 \mathrm{~mm}$ ). The ethanolic extracts from nine Begonia plant species were evaluated for their antimicrobial activity against methicillinresistant S. aureus (MRSA) strain. Extracts from all test Begonia plants caused a re- 
markable reduction in bacterial growth, measured as an inhibition zone diameters. The diameter of the inhibition zone for B. solimutata was (16.4 1.1$) \mathrm{mm}$, for B. goegoensis

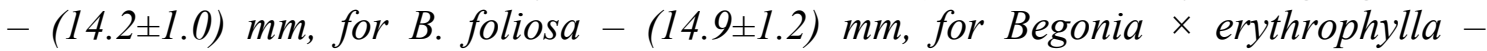

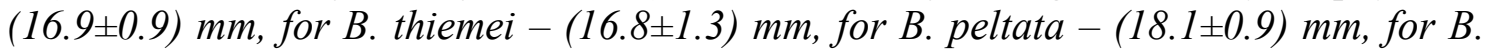
heracleifolia - (15.3 \pm 0.9$) \mathrm{mm}$, for $B$. dregei - $(14.7 \pm 1.1) \mathrm{mm}$, and for B. mexicana (13.8 \pm 0.9$) \mathrm{mm} /$ The highly active antimicrobial effects of extracts obtained from $B$. peltata and B. thiemei noted against S. aureus NCTC 12493 growth is worthy of highlighting. Our studies indicated that Begonia plants are worthy of further investigation as a potential phytotherapeutic agent for treating infections caused by S. aureus., as well as for the development of innovative feed and preventative products in animal husbandry.

Keywords: Begonia, ethanolic extracts, antimicrobial activities, KirbyBauer disc diffusion susceptibility test protocol

Staphylococcus aureus, a major human and veterinary pathogen worldwide, can trigger a variety of infectious diseases, such as skin and soft tissue infections, endocarditis, osteomyelitis, bacteremia, and lethal pneumonia $[8,16]$. It is generally accepted that the clinical use of methicillin has led to the appearance of methicillin-resistant $S$. aureus (MRSA) [16]. Different MRSA clones have resulted from the independent acquisition of staphylococcal cassette chromosome mec (SCCmec), which contains genes encoding proteins that render the bacterium resistant to most $\beta$-lactam antibiotics (such as methicillin), by several $S$. aureus clones [17]. However, according to a new study methicillin-resistant $S$. aureus (MRSA) emerged long before the introduction of the antibiotic methicillin into clinical practice [9].

The most common ways to overcome antibiotic resistance are to develop new drugs or the development of combined treatment therapy. However, combining antibiotics may also make their adverse effects more pronounced [7, 15]. The discovery and development of antibacterial natural products, which are becoming increasingly popular are an alternative method for controlling diseases caused by S. aureus [21]. Moreover, despite intensive drug discovery efforts, no new classes of antibiotics have been developed into new medicines for recent decades [26].

Extensive bioprospecting studies are carried out to discover the tremendous medicinal potential of various plant species from biodiversity-rich areas of the world [18]. For example, the medicinal plants used as an alternative therapeutic option against bovine mastitis can act as an antibacterial, anti-inflammatory, or immune-modulatory agents which need to be explored [18]. Diaz Carrasco and co-workers (2016) have reviewed the scientific studies analyzing the potential of plant extracts as alternative feed additives to reduce necrotic enteritis in poultry, with a focus on two types of plant products that arise as promising candidates: tannins and essential oils. However, their application in poultry production has been largely avoided due to inconsistent evaluation of their efficacy and lack of full understanding of the modes of action behind them. Some of these products showed antimicrobial activity against Clostridium perfringens and coccidia in vitro and in vivo and can increase product performance, emulating the bioactive properties of in-feed antimicrobial growth promoters [6]. Extracts and essential oils from plants are important natural sources of pesticides. These compounds are considered an alternative to control ectoparasites of veterinary importance. Batista and coworkers (2016) have reported the insecticidal effects of essential oils and extracts obtained from Schinus molle against Ctenocephalides felis felis, a predominant flea that infests dogs and cats in Brazil [3]. Khosravi and co-workers (2016) have evaluated the inhibitory efficacy of Zataria multiflora Boiss., Thymus kotschyanus Boiss. \& Hohen., Mentha spicata L., Artemisia sieberi Besser, Rosmarinus officinalis L., and Heracleum 
persicum Desf. ex Fisch., C. A. Mey. \& Avé-Lall. essential oils against pathogenic Malassezia isolates, contributing to the pathogenesis of atopic dermatitis in dogs. The essential oils of $Z$. multiflora and T. kotschyanus showed strong antifungal activity against pathogenic Malassezia species tested [14].

Plants belonging to the Begonia L. genus can be good candidates for as an alternative therapy in restricting the resistant infectious organisms. Some of Begonia species were previously reported for their antimicrobial activities $[1,5,10,11,23,24]$. The antimicrobial activities of biogenic volatile organic compounds of intact plants of $24 \mathrm{Be}$ gonia species have been assessed against several pathogenic microorganisms (i.e. Staphylococcus epidermidis, Escherichia coli, and Candida albicans). As a result, 14 Begonia species, possessing well-expressed phytoncide activity have been recommended to use as indoor plants, based on their ability to reduce microbial air pollution indoor by a factor of 1,5-3,0 in particular, by decreasing the Staphylococcus aureus load $[12,13,25]$.

The present study was designed to assess the anti-MRSA activity of the ethanolic extracts obtained from the leaves of Begonia species plants, cultivated under glasshouse conditions at M.M. Gryshko National Botanic Garden (NBG), National Academy of Science of Ukraine (Kyiv, Ukraine).

Materials and Methodology. Collection of Plant Materials. The leaves of Begonia plants, cultivated under glasshouse conditions, were sampled at M.M. Gryshko National Botanical Garden (NBG), National Academy of Science of Ukraine. The leaves of B. solimutata L.B. Sm. \& Wassh., B. goegoensis N.E.Br., B. foliosa Kunth, B. $\times$ erythrophylla Hérincq, B. thiemei C.DC. (syn. Begonia macdougallii Ziesenh.), $B$. peltata Otto \& Dietr. (syn. Begonia kellermanii C.DC.), B. heracleifolia Cham. \& Schltdl., B. dregei Otto \& Dietr., B. mexicana G. Karst. ex Fotsch were sampled for the current study.

Preparation of Plant Extracts. The leaves were brought into the laboratory for antimicrobial studies. Freshly crushed leaves were washed, weighed, and homogenized in $96 \%$ ethanol (in proportion 1:19) at room temperature. The extracts were then filtered and investigated for their antimicrobial activity.

Determination of the antibacterial activity of plant extracts by the disk diffusion method. For the current study, the strain of S. aureus NCTC 12493 (mecA positive, Methicillin-resistant, EUCAST QC strain for cefoxitin) was used. The testing of the antibacterial activity of the plant extracts was carried out in vitro by the Kirby-Bauer disc diffusion technique [4]. The strain was inoculated onto Mueller-Hinton (MH) agar plates. Sterile filter paper discs impregnated with extracts were applied over each of the culture plates. Isolates of bacteria were then incubated at $37^{\circ} \mathrm{C}$ for $24 \mathrm{~h}$. The plates were then observed for the zone of inhibition produced by the antibacterial activity of ethanolic extracts obtained from the leaves of various extracts of plants belonging to the $B e$ gonia genus. A negative control disc impregnated with sterile ethanol was used in each experiment. For each extract, eight replicates were assayed. The plates were observed and photographs were taken. The susceptibility of the test organism to the plant extracts was indicated by a clear zone of inhibition around the holes containing the plant extracts and the diameter of the clear zone was taken as an indicator of susceptibility. Zone diameters were determined and averaged.

Statistical analysis. All statistical calculation was performed on separate data from each extract. The data were analyzed using a one-way analysis of variance (ANOVA) using Statistica v. 8.0 software (StatSoft, Poland) [27]. The following zone diameter criteria were used to assign susceptibility or resistance of bacteria to the phy- 
tochemicals tested: Susceptible $(\mathrm{S}) \geq 15 \mathrm{~mm}$, Intermediate $(\mathrm{I})=10-15 \mathrm{~mm}$, and Resistant $(\mathrm{R}) \leq 10 \mathrm{~mm}[19]$.

Results and discussion. The ethanolic extracts from nine Begonia plant species were evaluated for their antimicrobial activity against methicillin-resistant $S$. aureus (MRSA) strain. As shown in Fig. 1, extracts from all test Begonia plants caused a remarkable reduction in bacterial growth, measured as an inhibition zone diameters. The diameter of the inhibition zone for B. solimutata was $(16.4 \pm 1.1) \mathrm{mm}$, for B. goegoensis - (14.2 \pm 1.0$) \mathrm{mm}$, for B. foliosa - $(14.9 \pm 1.2) \mathrm{mm}$, for Begonia $\times$ erythrophylla $(16.9 \pm 0.9) \mathrm{mm}$, for $B$. thiemei - $(16.8 \pm 1.3) \mathrm{mm}$, for $B$. peltata $-(18.1 \pm 0.9) \mathrm{mm}$, for $B$. heracleifolia - $(15.3 \pm 0.9) \mathrm{mm}$, for $B$. dregei $-(14.7 \pm 1.1) \mathrm{mm}$, and for $B$. mexicana (13.8 \pm 0.9$) \mathrm{mm}$ (Fig. 1).

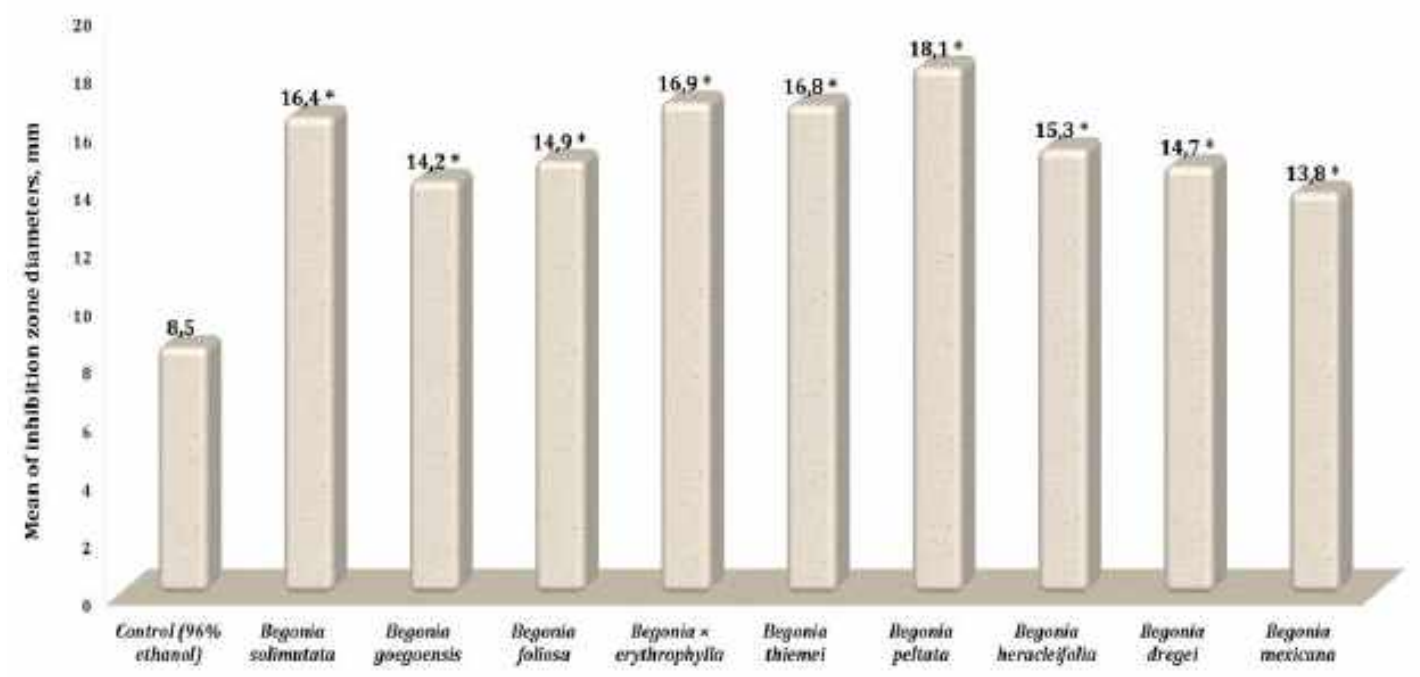

Fig. 1. The mean inhibition zone diameters around S. aureus NCTC 12493 growth induced by various ethanolic extracts obtained from leaves of Begonia plants $(\mathbf{M} \pm \mathbf{m}, \mathbf{n}=\mathbf{8})$.

* - statistically significant changes $(p<0.05)$ in comparison with the control sample values (96\% ethanol).

Detailed data regarding the zones of inhibition by the various plant extracts were recorded and presented in Fig. 2.
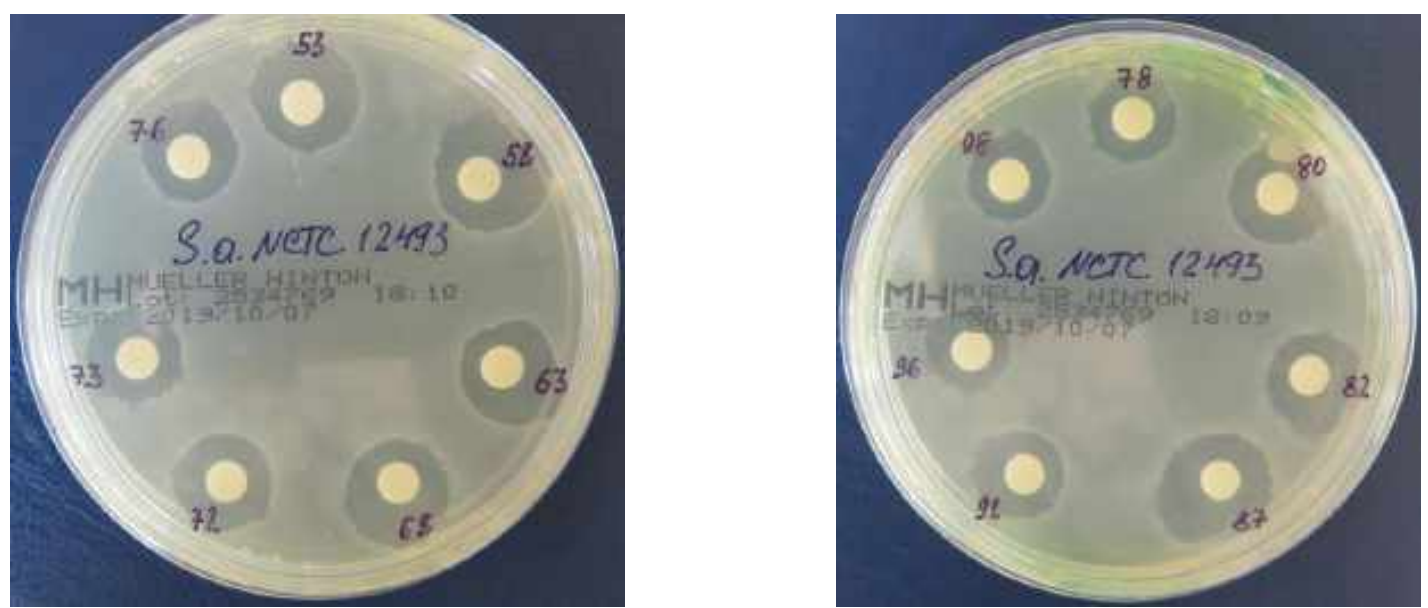

Fig. 2. Inhibition zones induced by various ethanolic extracts obtained from leaves of $B$. solimutata (73), B. goegoensis (76), B. foliosa (78), Begonia $\times$ erythrophylla (80), B. thiemei (82), B. peltata $(87)$, B. heracleifolia $(91)$, B. dregei (96), and $B$. mexicana (98) against $S$. aureus NCTC 12493 growth 
It should be noted that the most effective plants among plant extracts screened against $S$. aureus NCTC 12493 growth were B. peltata, B. thiemei, B. foliosa, Begonia $\times$ erythrophylla, and $B$. solimutata being highly active with the ethanolic extracts (diameters of inhibition zone ranged from 12.5 to $21 \mathrm{~mm}$ ). The highly active antimicrobial effects of extracts obtained from $B$. peltata and $B$. thiemei noted against $S$. aureus NCTC 12493 growth is worthy of highlighting.

Our previous findings [24] indicated, that the ethanolic extracts obtained from leaves of Begonia species possessed moderate activity against Escherichia coli. The highest antimicrobial effect was recorded for B. peltata, B. mexicana, and B. thiemei. The most antimicrobial effective plant against $E$. coli was $B$. peltata, being highly active with the ethanolic extract (diameter of inhibition zone was $19 \mathrm{~mm}$ ) [24]. Moreover, the ethanolic extract derived from the leaves of B. goegoensis exhibited strong activity against Pseudomonas aeruginosa (inhibition zone diameter ranged from 12 to $13 \mathrm{~mm}$ ), while methanolic leaf extract screened exhibited a relatively low inhibition effect (within the range of 11-12.5 mm) on the target pathogen [23]. Ethanolic extracts obtained from leaves of Begonia plants exhibited high activity against Citrobacter freundii strain [5]. The most effective plants among species screened against Citrobacter freundii locally isolated were $B$. thiemei, B. foliosa, and Begonia $\times$ erythrophylla being highly active with the ethanolic extract (diameters of inhibition zone ranged from 16.5 to 26 $\mathrm{mm}$ ). The highly active antimicrobial effects of extracts obtained from B. thiemei, B. foliosa noted against Citrobacter freundii are worthy of highlighting [5].

Similar antimicrobial effect of various Begonia plant species was also reported by other researchers. For example, Siregar and co-workers (2018) have demonstrated the antibacterial potency of simple fractions of ethyl acetate extract of B. baliensis Girm. from the forest area of Bukit Sangyang, Penebel, Tabanan-Bali against Escherichia coli, Bacillus subtilis, Staphylococcus epidermidis, and Staphylococcus aureus [22].

Variation in the chemical profile of extracts could influence their biological activities. Therefore, it was important to evaluate the chemical composition of extracts to correlate with their antimicrobial activities. The preliminary phytochemical studies revealed the presence of flavone, sterol, triterpene in hexane, chloroform, and methanol extracts; phenol in chloroform and methanol extracts and quinone, saponin, tannin, and starch in methanol extract of $B$. malabarica [20]. Preliminary phytochemical screening of B. floccifera and B. malabarica conducted by Ariharan and co-workers (2012) showed the presence of vitamin $C$ in the leaves of both plant species assayed [2]. Additionally, the flavonoids content (including glycosides of quercetin and kaempferol), anthocyanins and ascorbic acid in overground part of plants of 7 species and cultivars of genus Begonia (B. bahiensis, B. bowerae, B. carolineifolia, B. fischeri, B. heracleifolia, $B$. 'Erythrophylla', $B$. 'Helen Teupel') was evaluated by Karpova and co-workers (2009) [13]. The flavonoids content was $24-650 \mathrm{mg} \%$ of dry weight, including glycosides of quercetin $-3-76 \mathrm{mg} \%$. Kaempferol glycosides were detected only in species of section Gireoudia (1.2-5.7 mg\%). The contents of anthocyanins were between 60 and $157 \mathrm{mg} \%$, ascorbic acid $-5-43 \mathrm{mg} \%$ of fresh weight. These results suggest that studied plants of Begonia species can be considered as the sources of biologically active compounds with promising antioxidant and antimicrobial activities [12, 13].

Conclusions. In conclusion, the selected plants belonging to the Begonia genus has mild activity against MRSA strain, which represents the most frequent cause of complicated infections worldwide. This study showed that ethanolic leaf extracts of $B e$ gonia peltata, B. thiemei, B. foliosa, Begonia $\times$ erythrophylla, and B. solimutata were the most effective plants among species screened against methicillin-resistant $S$. aureus 
(MRSA) and could be potential sources of new antimicrobial agents, what can be used to develop innovative feed and preventative products in animal husbandry. However, more studies on the both in vitro and in vivo antimicrobial activity, bioavailability, and mechanism of action of active compounds derived from extracts are needed to be conducted.

\section{References}

1. Amutha S., \& Sreedevikumari, T. (2016). Evaluation of antibacterial activity of different solvent extracts of Begonia cordifolia. Int. J. Zool. Appl. Biosci., 1(3), 144-147.

2. Ariharan, V. N., Meena Devi, V. N., Rajakokhila, M., \& Nagendra Prasad, P. (2012). A new natural source for vitamin C. International Journal of Plant, Animal and Environmental Sciences, 2(3), 92-94.

3. Batista, L. C., Cid, Y. P., De Almeida, A. P., Prudêncio, E. R., Riger, C. J., De Souza, M. A., Coumendouros, K., \& Chaves, D. S. (2016). In vitro efficacy of essential oils and extracts of Schinus molle L. against Ctenocephalides felis felis. Parasitology, 143(5), 627-638.

4. Bauer, A. W., Kirby, W. M., Sherris, J. C., \& Turck, M. (1966). Antibiotic susceptibility testing by a standardized single disk method. Am. J. Clin. Pathol., 45(4), 493-496.

5. Buyun, L., Tkachenko, H., Kurhaluk, N., Góralczyk, A., Tomin, V., \& Osadowski, Z. (2019). Screening for antimicrobial activity of nine ethanolic extracts obtained from leaves of Begonia plant: a possible alternative in the treatment of infections caused by Citrobacter freundii. Agrobiodiversity for Improving Nutrition, Health, and Life Quality, (3), 312-322.

6. Diaz Carrasco, J. M., Redondo, L. M., Redondo, E. A., Dominguez, J. E., Chacana, A. P., \& Fernandez Miyakawa, M. E. (2016). Use of Plant Extracts as an Effective Manner to Control Clostridium perfringens Induced Necrotic Enteritis in Poultry. Biomed. Res. Int., 2016, 3278359.

7. Garnacho-Montero, J., Amaya-Villar, R., Gutiérrez-Pizarraya, A., EspejoGutiérrez de Tena, E., Artero-González, M. L., Corcia-Palomo, Y., \& BautistaPaloma, J. (2013). Clinical efficacy and safety of the combination of colistin plus vancomycin for the treatment of severe infections caused by carbapenem-resistant Acinetobacter baumannii. Chemotherapy, 59(3), 225-231.

8. Guo, Y., Song, G., Sun, M., Wang, J., \& Wang, Y. (2020). Prevalence and Therapies of Antibiotic-Resistance in Staphylococcus aureus. Front. Cell Infect. Microbiol., 10, 107.

9. Harkins, C. P., Pichon, B., Doumith, M., Parkhill, J., Westh, H., Tomasz, A., de Lencastre, H., Bentley, S.D., Kearns, A.M., \& Holden, M.T.G. (2017). Methicillin-resistant Staphylococcus aureus emerged long before the introduction of methicillin into clinical practice. Genome Biol., 18(1), 130.

10. Holetz, F. B., Pessini, G. L., Sanches, N. R., Cortez, D. A., Nakamura, C. V., \& Filho, B. P. (2002). Screening of some plants used in Brazilian folk medicine for the treatment of infectious diseases. Mem. Inst. Oswaldo Cruz, 97, 1027-1031.

11. Indrkumar, I., Gomathi, R., \& Karpagam, S. (2014). Antimicrobial and In vitro Antioxidant Potential of Begonia dipetala Graham. Int. J. Pharm. Sci. Rev. Res., 27(2), 382-386.

12. Karpova, E., Nabieva, A., Fershalova, T., Yakimova, Y., \& Tsybulya, N. (2019). Flavonoids and Antimicrobial Properties of Begonia fischeri var. palustris in vitro Plantlets. OnLine Journal of Biological Sciences, 19(1), 20-27. 
13. Karpova, E. A., Kchramova, E. P., \& Fershalova, T. D. (2009). Flavonoids and ascorbic acid in the representatives of the genus Begonia L. Chemistry of Plant Raw Material, 2, 105-110.

14. Khosravi, A. R., Shokri, H., \& Fahimirad, S. (2016). Efficacy of medicinal essential oils against pathogenic Malassezia sp. isolates. J. Mycol. Med., 26(1), 28-34.

15. Kuok, C. F., Hoi, S. O., Hoi, C. F., Chan, C. H., Fong, I. H., Ngok, C. K., Meng, L. R., \& Fong, P. (2017). Synergistic antibacterial effects of herbal extracts and antibiotics on methicillin-resistant Staphylococcus aureus: A computational and experimental study. Exp. Biol. Med. (Maywood), 242(7), 731-743.

16. Lakhundi, S., \& Zhang, K. (2018). Methicillin-Resistant Staphylococcus aureus: Molecular Characterization, Evolution, and Epidemiology. Clin. Microbiol. Rev., 31(4), e00020-18.

17. Lee, A. S., de Lencastre, H., Garau, J., Kluytmans, J., Malhotra-Kumar, S., Peschel, A., \& Harbarth, S. (2018). Methicillin-resistant Staphylococcus aureus. Nat. Rev. Dis. Primers, 4, 18033.

18. Mushtaq, S., Shah, A. M., Shah, A., Lone, S. A., Hussain, A., Hassan, Q. P., \& Ali, M. N. (2018). Bovine mastitis: An appraisal of its alternative herbal cure. Microb. Pathog., 114, 357-361.

19. Okoth, D. A., Chenia, H. Y., \& Koorbanally, N. A. (2013). Antibacterial and antioxidant activities of flavonoids from Lannea alata (Engl.) Engl. (Anacardiaceae). Phytochem. Lett., 6, 476-481.

20. Ramesh, N., Viswanathan, M. B., Saraswathy, A., Balakrishna, K., Brindha, P., \& Lakshmanaperumalsamy, P. (2002). Phytochemical and antimicrobial studies of Begonia malabarica. J. Ethnopharmacol., 79(1), 129-132.

21. Simões, M., Bennett, R. N., \& Rosa, E. A. (2009). Understanding antimicrobial activities of phytochemicals against multidrug resistant bacteria and biofilms. Nat. Prod. Rep., 26(6), 746-757.

22. Siregar, H. M., Purwantoro, R. S., \& Praptiwi Agusta, A. (2018). Antibacterial potency of simple fractions of ethyl acetate extract of Begonia baliensis. Nusantara Bioscience, 10, 159-163.

23. Tkachenko, H., Buyun, L., \& Osadowski, Z. (2017). The antimicrobial properties of extracts obtained from Begonia goegoensis N.E.Br. leaf against Pseudomonas aeruginosa isolates. Agrobiodiversity for Improving Nutrition, Health, and Life Quality, 1, 454-460.

24. Tkachenko, H., Buyun, L., Osadowski, Z., \& Belayeva, Y. (2016). In vitro microbiological investigation of ethanolic extracts obtained from leaves of various $B e$ gonia species against Escherichia coli. Stupskie Prace Biologiczne, 13, 277-294.

25. Tsybulya, N. V., Fershalova, T. D., \& Yakimova, Yu. L. (2010). Examination of the antimicrobial activity of some Begonia L. species as a possible piece of phytodesign. Aerospace and Environmental Medicine, 44(1), 47-50.

26. Tyers M., \& Wright G. D. (2019). Drug combinations: a strategy to extend the life of antibiotics in the $21^{\text {st }}$ century. Nat. Rev Microbiol., 17(3), 141-155.

27. Zar J. H. (1999). Biostatistical Analysis. $4^{\text {th }}$ ed., Prentice-Hall Inc., Englewood Cliffs, New Jersey. 
СКРИНІНГ IN VITRО АНТИМІКРОБНОГО ПОТЕНЦІАЛУ ЕТАНОЛЬНИХ ЕКСТРАКТІВ ЛИСТКІВ ДЕЯКИХ ВИДІВ ВЕGОNІА ПО ВІДНОШЕННЮ ДО МЕТИЦИЛІН-РЕЗИСТЕНТНОГО ШТАМУ STAPHYLOCOCCUS AUREUS (MRSA)

Ткаченко Г., Кургалюк Н., Інститут біологї̈ та наук про Землю, Поморська Академія у Слупську, Польща.

Буюн Л., Національний ботанічний сад імені М. М. Гришка, Національна академія наук України.

Томін В., Поморська Академія у Слупську, Польща.

Було досліджено антимікробну активність етанольних екстрактів листків різних видів Begonia - Begonia solimutata L.B. Sm. \& Wassh., Begonia goegoensis N.E.Br., Begonia foliosa Kunth, Begonia $\times$ erythrophylla Hérincq, Begonia thiemei C.DC., Begonia peltata Otto \& Dietr., Begonia heracleifolia Cham. \& Schltdl., Begonia dregei Otto \& Dietr., ma Begonia mexicana G. Karst. ex Fotsch по відношенню до метииилін-резистентного штаму Staphylococcus aureus (MRSA). Листя приносили в лабораторію для антимікробних досліджень. Свіжовичавлені подрібнені листя промивали, зважували і гомогенізували в 96\% - ному етанолі (в пропориії 1:19) при кімнатній температурі. Потім екстракти фільтрували і досліджували їх антимікробну активність. Аналіз антибактеріальної активності рослинних екстрактів здійснювали за допомогою диско-дифузійного тесту Кірбі-Бауера. Етанольні екстракти дев'яти видів рослин бегонії були оцінені на предмет їх антимікробної активності щзодо метициллінрезистентного штаму S. aureus (MRSA). Екстракти з усіх тестових рослин бегонії викликали помітне зниження бактеріального росту, вимірюваного як діаметри зон інгібування. Діаметр зони інгібування для B. solimutata склав $(16,4 \pm 1,1)$ мм, для B. goegoensis- $(14,2 \pm 1,0)$ мм, для B. foliosa - $(14,9 \pm 1,2)$ мм, для Begonia x erythrophylla - $(16,9 \pm 0,9)$ мм, для В. thiemei- $(16,8 \pm 1,3)$ мм, для B. peltata - $(18,1 \pm 0,9)$ мм, для B. heracleifolia- $(15,3 \pm 0,9)$ мм, для В. dregei - $(14,7 \pm 1,1)$ мм, а для В. техісапа - $(13,8 \pm 0,9)$ мм. Серед досліджених видів рослин найбільш ефективними щодо здатності інгібувати ріст $S$. aureus NCTC 12493 виявились B. peltata, B. thiemei, B. foliosa, Begonia $\times$ erythrophylla та B. solimutata; при використанні етанольних екстрактів листків цих видів діаметр зони інгібування становив від 12,5 до 21 мм. На особливу увагу заслуговують B. peltata $i$ B. thiemеi, які виявили надзвичайно високу активність по відношенню до штаму S. aиrеиs NCTC 12493. Отже, наші дослідження свідчать про те, щуо представники роду Веgопіа потребують подальших досліджень як джерело потенційних фітотерапевтичних засобів для лікування інфекцій, спричинених S. Aureus, а також для розробки інновачійних кормових і профілактичних засобів у тваринництві.

Ключові слова: Bеgопіа, етанольні екстракти, антимікробна активність, диско-дифузійний метод на чутливість Кірбі-Бауера 
СКРИНИНГ IN VITRO АНТИМИКРОБНОГО ПОТЕНЦИАЛА ЭТАНОЛЬНЫХ ЭКСТРАКТОВ ЛИСТЬЕВ НЕКОТОРЫХ ВИДОВ ВЕGОNIA ПО

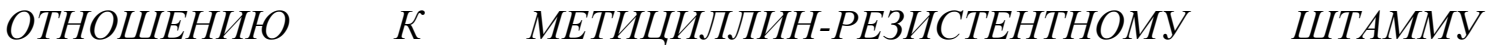
STAPHYLOCOCCUS AUREUS (MRSA)

Ткаченко Г., Кургалюк Н., Институт биологии и наук о Земле, Поморская академия в Слупске, Польша.

Буюн Л., Наџиональный ботанический сад имени Н. Н. Гришко, Наџиональная академия наук Украины.

Томин В., Поморская Академия в Слупске, Польша.

Была исследована антимикробная активность этанольных экстрактов листьев разных видов Begonia - Begonia solimutata L.B. Sm. \& Wassh., Begonia goegoensis N.E.Br., Begonia foliosa Kunth, Begonia $\times$ erythrophylla Hérincq, Begonia thiemei C.DC., Begonia peltata Otto \& Dietr., Begonia heracleifolia Cham. \& Schltdl., Begonia dregei Otto \& Dietr. u Begonia mexicana G. Karst. ex Fotsch по отношению $\kappa$ метициллин-резистентному штамму Staphylococcus aureus (MRSA). Листья приносили в лабораторию для антимикробных исследований. Свежие измельченные листья промывали, взвешивали и гомогенізували в 96 \% - ном этаноле (в пропориии 1:19) при комнатной температуре. Затем экстракты фильтровали и исследовали их антимикробную активность. Анализ антибактериальной активности растительных экстрактов осуществляли при помощи диско-диффузионного теста Кирби-Бауэра. Этанольные экстракты девяти видов растений бегонии были оценены на предмет их антимикробной активности в отношении метициллинрезистентного итамма S. aureus (MRSA). Как показано на фиг. 1, экстракть из всех тестовых растений бегонии вызывали заметное снижение бактериального роста, измеряемого как диаметры зон ингибирования. Диаметр зоны ингибирования для B. solimutata составил $(16,4 \pm 1,1)$ мм, для B. goegoensis- $(14,2 \pm 1,0)$ мм, для B. foliosa - $(14,9 \pm 1,2)$ мм, для Begonia $\times$ erythrophylla $-(16,9 \pm 0,9)$ мм, для B. thiemei - $(16,8 \pm 1,3)$ мм, для B. peltata - $(18,1 \pm 0,9)$ мм, для B. heracleifolia $(15,3 \pm 0,9)$ мм, для B. Dregei - $(14,7 \pm 1,1)$ мм, а для B. mexicana - $(13,8 \pm 0,9)$ мм. Среди исследованных видов растений наиболее эффективными в отнотении способности ингибировать рост S. aureus NCTC 12493 оказались B. peltata, B. thiemei, B. foliosa, Begonia $\times$ erythrophylla и B. solimutata; при использовании этанольных экстрактов листьев этих видов диаметр зоны ингибирования составил от 12,5 до 21 мм. Особого внимания заслуживают B. peltata u B. thiemei, обнаружившие чрезвычайно высокую активность в отношении штамма $S$. aureus NCTC 12493. Таким образом, наши исследования свидетельствуют о том, что представители рода Веgопіа требуют дальнейших исследований в качестве источника потенциальных фитотерапевтических средств для лечения инфекций, вызванных S. Aureus, а также для разработки инновационных кормовых и профилактических средств в животноводстве.

Ключевые слова: Веgопіа, этанольные экстракты, антимикробная активность, диско-диффузийный метод Кирби-Бауэра 